University of Wollongong

Research Online

Faculty of Law, Humanities and the Arts Papers (Archive)

Faculty of Arts, Social Sciences \& Humanities

$1-1-2011$

International trade and development law: a legal cultural critique

Colin B. Picker

University of New South Wales, cpicker@uow.edu.au

Follow this and additional works at: https://ro.uow.edu.au/lhapapers

Part of the Arts and Humanities Commons, and the Law Commons

Research Online is the open access institutional repository for the University of Wollongong. For further information contact the UOW Library: research-pubs@uow.edu.au 


\title{
International trade and development law: a legal cultural critique
}

\author{
Abstract \\ To the extent that international trade and development policy employs legal methods, institutions and \\ participants, there is a need to take into account the role of legal culture. There are many different legal \\ cultures in the world, including the widely found common and civil law traditions, as well as the many non- \\ western legal traditions and sub-traditions found within the hundreds of different legal systems spread \\ across the globe. International law has, however, traditionally eschewed consideration of legal culture- \\ arguing that international law is unique, is sui generis, and as such domestic legal traditions were not \\ relevant. Yet, the humans involved in creating and nurturing international legal fields and institutions will \\ themselves reflect the legal culture of their home states, and will often import aspects of those legal \\ cultures into international law. The same must be true of international development law. In addition, \\ international legal fields, such as international development law, must often work within domestic legal \\ systems, and as such they will directly interact with the domestic legal traditions. It is thus important to \\ understand the interaction between the legal cultures reflected in the relevant part of that international \\ law and in that of the domestic legal system. Such an understanding can be useful in ensuring the \\ effective interaction of the two systems. This paper explores these themes, continuing the author's past \\ and ongoing consideration of the role of legal culture in international law, including its role within \\ institutions such as the World Trade Organization.

\section{Disciplines} \\ Arts and Humanities | Law \\ Publication Details \\ C. B. Picker, 'International trade and development law: a legal cultural critique' (2011) 4 (2) The Law and \\ Development Review 43-71.
}




\title{
The Law and Development Review
}

Volume 4, Number 2

2011

Article 4

SPECIAL ISSUE (2011): THE LAW AND DEVELOPMENT INSTITUTE

2010 INAUGURAL CONFERENCE

\section{International Trade and Development Law: A Legal Cultural Critique}

\author{
Colin Picker, University of New South Wales
}

\section{Recommended Citation:}

Picker, Colin (2011) "International Trade and Development Law: A Legal Cultural Critique," The Law and Development Review: Vol. 4: No. 2, Article 4.

Available at: $\mathrm{http}: / / \mathrm{www} \cdot$ bepress.com/ldr/vol4/iss $2 /$ art4

DOI: $10.2202 / 1943-3867.1092$

C2011 The Law and Development Review. All rights reserved. No part of this publication may be reproduced, stored in a retrieval system, or transmitted, in any form or by any means, electronic, mechanical, photocopying, recording, or otherwise, without the prior written permission of the Law and Development Review. 


\title{
International Trade and Development Law: A Legal Cultural Critique
}

\author{
Colin Picker
}

\begin{abstract}
To the extent that international trade and development policy employs legal methods, institutions and participants, there is a need to take into account the role of legal culture. There are many different legal cultures in the world, including the widely found common and civil law traditions, as well as the many non-western legal traditions and sub-traditions found within the hundreds of different legal systems spread across the globe. International law has, however, traditionally eschewed consideration of legal culture - arguing that international law is unique, is sui generis, and as such domestic legal traditions were not relevant. Yet, the humans involved in creating and nurturing international legal fields and institutions will themselves reflect the legal culture of their home states, and will often import aspects of those legal cultures into international law. The same must be true of international development law. In addition, international legal fields, such as international development law, must often work within domestic legal systems, and as such they will directly interact with the domestic legal traditions. It is thus important to understand the interaction between the legal cultures reflected in the relevant part of that international law and in that of the domestic legal system. Such an understanding can be useful in ensuring the effective interaction of the two systems. This paper explores these themes, continuing the author's past and ongoing consideration of the role of legal culture in international law, including its role within institutions such as the World Trade Organization.
\end{abstract}

KEYWORDS: international development law, World Trade Organization

Author Notes: Professor Picker is an Associate Professor at the Law Faculty of the University of New South Wales. 
Picker: International Trade and Development Law: A Legal Cultural Critique

\section{INTRODUCTION}

The goal of this paper is to present a methodology, a legal cultural analysis, through application of that methodology to a specific issue-international development law. As an initial matter, this paper will engage in a brief legal cultural analysis of the field as a whole. The paper will then present a more detailed legal cultural analysis of one of the institutions involved in international development law - the WTO. Finally, the paper will then undertake an analysis of the legal cultural issues that may arise during domestic implementation of international development law. Nonetheless, this paper is as much about suggesting a way of thinking about international development law as it is intended to convey content. Indeed, the nature of the underlying subject matter, international development law, is so often the source of disagreement and controversy that the substantive analysis may itself in some cases be so contested as to rule out its general utility. ${ }^{1}$ The neutral methodology, in contrast, that is showcased in this paper should prove to be a highly beneficial methodology for international development law and other international fields. Indeed, this paper is really part of an ongoing larger body of work of the author - a more comprehensive trial of the legal cultural methodology within international law, focusing on the World Trade Organization (the "WTO"). As such, many of the examples in this paper will be taken from the WTO context. ${ }^{2}$ That work is itself a continuation of previous comparative analyses of international law as a whole. ${ }^{3}$ To the extent that international development law employs legal methods, institutions, and participants, then it is also a field for which this legal cultural methodology may be usefully employed.

There are many different legal cultures in the world, including those found in the dominant western common and civil law traditions. In addition, there are

1 Daniel D. Bradlow, Development Decision Making and the Content of International Development Law, 27 Boston College International and Comparative Law Review (2004), 195.

${ }^{2}$ The research here is part of a larger study by the author that will be part of the author's $\mathrm{PhD}$ thesis. Some of it has already been published. See, for example, Colin B. Picker (Picker (WTO)), "A Framework for Comparative Analyses of International Law and its Institutions: Using the Example of the World Trade Organization", in E.C. Ritaine, S.P. Donlan and M. Sychold (eds.), Comparative Law and Hybrid Legal systems (Swiss Institute of Comp. Law, 2010); Colin B. Picker (Picker (China)), China, Global Governance \& Legal Culture: The Example of China \& the WTO, Parts 1 of 4, Proceedings of the University of Tokyo Institute of Social Science. (forthcoming January 2011); Colin B. Picker (Picker (Methodology)), Comparative Law Methodology \& American Legal Culture: Obstacles and Opportunities, Roger Williams University of Law Review (forthcoming, January 2011).

${ }^{3}$ See, for example, Colin B. Picker (Picker (International Law)), International Law's Mixed Heritage: A Common/Civil Law Jurisdiction, 41 Vanderbilt Journal of Transnational Law (2008), 1093; Colin B. Picker, Beyond the Usual Suspects: Application of the Mixed Jurisdiction Jurisprudence to International Law and Beyond, 3 Journal of Comparative Law (2008), 160. 
many non-western legal traditions and sub-traditions found within the hundreds of different legal systems spread across the globe. International law and its subfields have, however, traditionally eschewed consideration of legal culture - arguing that international law is unique, is sui generis, and as such domestic legal traditions and cultures are essentially not relevant. ${ }^{4}$ Yet, the humans involved in creating and nurturing international legal fields and institutions will themselves reflect the legal culture of their home states, and will often import aspects of those legal cultures into international law and its institutions. Furthermore, they will, subconsciously for the most part, slowly and incrementally work together to create a legal culture for their institutions and fields. For those international law institutions and fields that have existed for decades, one would expect such a legal culture to be relatively well developed. That legal culture will then manifest itself in particular in its interactions with the state-based legal systems and cultures with which the international institution or field operates. ${ }^{5}$ The same must be true of international development law, for it too comprises individuals, working to a common purpose, building up institutional and substantive experience and knowledge, and in the process creating a legal culture for international development law.

As an initial matter, let me define international development law. It is "the branch of international law dealing with the rights and responsibilities of states and other actors in the [economic] development process." "Admittedly, the term has too often been employed with little exactitude. Indeed, when this paper was presented at the Law \& Development Institute Inaugural Conference, ${ }^{7}$ there were questions from the audience suggesting that it is not does not exist as a separate field and that even if it does exist it merely comprises a collection of unrelated "soft law." Compounding these definitional issues are the significant differences within the field based on ideology. Those ideological differences typically fall into one of two camps - those within the "traditionalist" and those within the "modern" (or the "new international economic order" (the "NIEO"). ${ }^{8}$ The traditional view:

[A]ssumes that development is primarily an economic process that consists of discrete projects (e.g., building a dam, a road, a school, a factory, a mine, or a telecommunications system) and specific economic policies. It recognizes that development has social, environmental, and political

\footnotetext{
${ }^{4}$ See, for example, Picker (International Law) (2008), supra note 3, p. 1090.

${ }^{5}$ Ibid.

${ }^{6}$ Bradlow (2004), supra note 1, p. 195.

${ }^{7}$ See Law \& Development Institute Inaugural Conference (Sydney, Australia, 16 October, 2010), available at: $<$ http://www.lawanddevelopment.net/program.php $>$.

${ }^{8}$ See Bradlow (2004), supra note 1, pp. 199-210.
} 
Picker: International Trade and Development Law: A Legal Cultural Critique

implications but argues that these should be dealt with separately from the economic aspects. ${ }^{9}$

The modern or NIEO view:

$[\mathrm{P}]$ osits that the economic aspects of development cannot be separated from its social, political, environmental, and cultural aspects and that development should be seen as a holistic, integrated process. From this perspective, development projects and policies should be treated not so much as discrete economic events but as episodes of social, economic, and environmental transformation that are part of an ongoing process of change. ${ }^{10}$

Given the disagreements about the existence and scope of the field, international development law is clearly a controversial subject for which any assistance, or indeed attention, that can therefore be brought to bear on the field would be of great service to it. Presenting a new methodology, the legal cultural analysis, will hopefully help the field.

One valuable benefit of the methodology is that it can help to close the gap between the two perspectives in that both are, for the most part, irrelevant to development of the analysis in this paper. This is because the issues of whether international development law includes only economic factors, or the social context, or whether the field's law is soft or hard or declaratory or obligatory, are merely a few of the many legal factors that will be considered in a legal cultural context. Without elevating any of these factors above the others, they are all a part of the analysis. In other words, whether the scope of development law includes environmental, social, or human rights or purely economic factors makes little difference when what is being considered is the legal cultural context - the legal outlook of the substantive law, actors, and institutions in the field. Though, understanding the legal culture of the different participants in international development law will also provide insights into why the modern or traditional perspectives might have been better received in some places and by some groups than by others.

Having defined international development law, it then just remains to define legal culture and legal cultural analysis. I have previously defined legal culture:

The term "legal culture" is not a term commonly employed or understood within the law. While other fields, such as social science, may have considered cultural issues in great depth, in law it is relatively rare. In part

\footnotetext{
${ }^{9} I d .$, p. 200.
}

${ }^{10} I d .$, p. 207. 
this may because it is viewed as too "soft". So, in order to give it greater strength I define legal culture to consist of those characteristics present in a legal system, reflecting the common history, traditions, outlook and approach of that system. Those characteristics may be reflected in the actions or behaviours of the actors, institutions, and even of the substance of the system. Legal culture exists not because of regulation of substantive law, but as a result of the collective response and actions of those participants in the legal system. As a result, legal culture can vary dramatically from country to country, even when the countries share a common legal tradition. Critically, legal culture is also to be found within international institutions and fields - for they too are legal systems. Those different legal cultures are critical for understanding the legal systems, for different legal cultures tell different stories, see the world differently, and project different visions. It should be emphasized that legal culture is not anthropology or sociology. For sure, culture is part of and studied by those two and other fields - often in ways of importance to the law. But, here, rather, everything that is a part of "legal culture" should be a cultural issue of legal consequence. Too often one can drift into non-law . . . . By way of example, to highlight the "legal" component of legal culture, the American or Anglo-American legal culture may be easily contrasted with that of the French or Japanese or Iranian. Thus, the differences in legal culture are clearly apparent when considering the expected role/behaviour/activities of Anglo-American judges versus those in civil law systems (passive versus active judicial behaviour); the role/behaviour/activities of American attorneys in business negotiations versus those in Japan (the significantly greater use of lawyers in the former versus the latter); and the role/character of legal sources in Anglo-American systems versus those in religious law systems (pluralistic and dynamic versus monolithic and difficult to change). Those specific legal cultural characteristics, simplified for sure in these examples, exist largely independently of statute, regulation or other positive law. They exist as part of the legal culture." 11

The power of this method can be tremendous. Typically, when considering conflicts and other issues between states, the legal analyses of international interactions will tend to focus on the formal legal exchanges between the states. Such a focus misses a vital layer of interaction - the legal cultural interaction. Indeed, the legal cultural disconnects, for there will always be such divides, may often be the root causes of enduring and repeated problems between states. This may be true even between two supposedly close and similar neighbors. For

${ }^{11}$ See Picker (China) (2011), supra note 2. 
example, the past dispute between the United States and Canada, two countries that are exceptionally close by most indicators, over the use of the law to protect culture, is itself exacerbated by legal cultures with opposing views on the role of law in, ironically, protecting culture and competition. ${ }^{12}$

Furthermore, legal cultural obstacles to good relations are unlike formal obstacles such as statutes, case law, and regulations that can be changed through the political process - albeit often at great difficulty, though formally possible in democratic systems. ${ }^{13}$ In other words, a simple legal issue concerning imperfect domestic implementation or even lack of transparency can be remedied by action of the government or appropriate political arrangement. But, matters of legal culture can be sticky obstacles - they are less easily overcome. For example, the European legal cultural attitude towards risk, exemplified through the precautionary principle, has proven remarkably difficult to budge despite repeated loss in cases involving that principle. ${ }^{14}$ At a more fundamental level, cultural obstacles, such as the legal culture of the judiciary that makes it subservient to the executive despite constitutional principles suggesting judicial independence, are more deeply imbedded, and thus, to the extent they serve as an obstacle, may be more problematic in the long run than simple legal conflicts. Too often such legal cultural characteristics are hard to see, hidden behind the formalism present in every legal system. Accordingly, identification of the legal cultural issues is the first step to dealing with such legal cultural conflicts.

Identification of the legal cultural issues in international development law is not an easy task. It can be done in many ways, but here it will be tackled in two broad but different approaches: (a) a holistic and (b) an atomistical approach. ${ }^{15}$ The holistic approach requires taking a look at international development law and legal culture from above. The atomistical approach requires taking a look from below. For each of the approaches there are benefits and detriments, but they are a good start for this initial foray into a legal cultural analysis of international development law. Though each will be discussed below, with conclusions and insights derived from each approach, there will always be the constraint that this

\footnotetext{
${ }^{12}$ See J. R. Paul, Cultural Resistance to Global Governance, 22 Michigan Journal of International Law (2000), 48.

${ }^{13}$ Even case law, so long as it does not touch on constitutional matters (and even then in some systems), can be changed through the political process - for there is almost always executive or parliamentary/legislative supremacy over the judiciary in all democratic systems for all nonconstitutional matters.

${ }^{14}$ See, for example, European Communities - Measures Affecting Meat Products (Hormones), WT/DS26/AB/R (16 January 1998).

${ }^{15}$ This is the first of many binary analytical approaches in this paper. A binary analysis, while often a simplification, is fundamentally the basic analysis one can perform - "something either is one thing or it is not" - to say it is between the two merely means that initial "something" was not originally identified with sufficient precision.
} 
is but one paper and the essential goal here is to demonstrate a novel and useful methodology.

\section{A Holistic Analysis of International DeVelopment LAW AND Legal CUlture}

At the holistic level, from 40,000 meters (or feet) international development law, to the extent it involves law-legal obligations, rights and duties - exists within international law. International law is defined to be those "[r]ules and principles of general application dealing with the conduct of nations and of international organizations and with their relations inter se as well as with some of their relations with persons, whether natural or juridical." 16 All transnational and international development activities, policies, obligations, and liabilities clearly fall within the ambit of international law. Of course, there is a great deal of development work that takes place solely in the domestic context of states. But, to the extent that domestic-based policy is not related to international rights and obligations, such as through the domestic implementation of international legal obligations related to development, then it is simply domestic policy. As such, it would not then be within the direct ambit of international law or even international development law. Of course, such independent domestic development law should be taken into account when considering the field of development as a whole. After all, the domestic development policy is likely to interact with those parts of international development law that take place within or demand resources or attention from states. It thus may conflict with or complement international development law. Nonetheless, when conducting a legal cultural analysis of international development law, the domestic development policy can be put aside, especially for that part of the analysis that is from a holistic perspective.

The holistic analysis of the legal culture of international development law can be elucidated through, once again, a binary approach. Namely, (a) that international development law is sufficiently similar to international law as to share the legal cultural issues of international law or (b) that it is sui generis within international law, and hence will have some different legal cultural issues.

\footnotetext{
${ }^{16}$ Restatement (Third) Foreign Relations $§ 101$ (American Law Institute) (1986).
} 
Picker: International Trade and Development Law: A Legal Cultural Critique

\section{A. The Legal Cultural Analysis: Similarities between International Development Law and International Law}

The first approach considered here is that international development law is sufficiently similar to general international law as to share its legal cultural issues. That position is quite defensible - for both the "hard" and "soft" international development law. Thus, Article XVIII of the GATT, which provides explicit ability for developing countries to engage in otherwise prohibited trade practices, such as employing tariff barriers to protect infant industries, is clearly "hard" law. ${ }^{17}$ Furthermore, as a rule that regulates state behavior within the international legal order, Article XVIII is without a doubt a solid part of international law-just as much a part of international law as are international rules concerning treaty interpretation. Similarly, with respect to the "soft" law within international development law, one can see a similar congruence with international law. For example, Part IV of the GATT is as much a part of international law, despite its inherent "softness" 18 as are the many other examples of accepted soft law within international law. One of the greatest examples of "soft law" in international law was the Kellogg-Briand Pact. ${ }^{19}$ While clearly soft in its early years, it was ignored by everyone, and was later employed as one of the sources of law to support the Nuremberg prosecutions. ${ }^{20}$ Accordingly, even though Part IV of the GATT has had little impact on states, if accorded sufficient time and perhaps some minor procedural modifications, it might also be transformed into "hard law". ${ }^{21}$ In the meantime, it is no less a part of international law than was the Kellogg-Briand Pact prior to Nuremberg. Given these realities, the consideration of international development law as being clearly within, and hence similar to, international law is not unjustified.

If international development law is similar to general international law, then one can credibly argue that the legal culture of international development law will be comparable to that of international law. Of course, this approach assumes that one can identify legal cultural characteristics for international law. Such a task is obviously difficult and not one typically undertaken by either international or comparative law scholars. After all, international law covers a tremendous

\footnotetext{
17 See Yong-Shik Lee, "Development and the World Trade Organization: Proposal for the Agreement on Development Facilitation and the Council for Trade and Development in the WTO", in Yong-Shik Lee (eds.), Economic Development through World Trade: A Developing World Perspective (The Hague: Klumer Law International, 2008), p. 6.

${ }^{18}$ Id., p. 8-9.

${ }^{19}$ General Treaty for Renunciation of War as an Instrument of National Policy (the "KelloggBriand Peace Pact of 1928”), 46 Stat. 2343, 94 L.N.T.S. 57 (27 August 1928), art. I.

${ }^{20}$ Michael J. Glennon, The Blank-Prose Crime of Aggression, 35 Yale Journal of International Law (2010), 71, 73.

${ }^{21}$ See Lee (2008), supra note 17 , p. 15.
} 
number of different subfields and issues, while comparative law does not normally handle international law fields. But, through the use of generalizations and simplifications, which are necessary evils in many comparative law examinations, an overarching legal culture of international law has been identified. $^{22}$ That analysis, admittedly not a definitive analysis, has nonetheless identified some salient characteristics and insights that may be highly relevant to an international development law that is itself a part of that international law.

Condensing that analysis, it was found that the legal culture of international law comprises some unique legal cultural elements; after all, the subjects of international law are sovereign states, but international law also draws heavily from both the civil law and common law traditions - but in a specific style and composition. Indeed, in the basic mix of those two traditions, in which parts they are strong and weak and in how they have been employed, the analysis suggested that they resemble the classical mixed jurisdiction systems of the world (such as Quebec, Scotland, etc). ${ }^{23}$ In other words, that:

The "basic building blocks" of these systems derive from the civil and common law traditions.

That, as a general matter, the public law is common law in style, while the private law, to the extent one can identify such within public international law, is more like civil law.

In addition to these overarching general characteristics, international law shares with the mixed jurisdictions similar:

(1) origins,

(2) judicial characters,

(3) linguistic issues,

(4) approaches to precedent and legal sources,

(5) receptions of the common law,

(6) receptions of Anglo-American procedure, and

(7) styles of commercial law."24

Thus, to the extent that international development law is comparable to general international law, then it too is likely mixed in some similar fashion. Of course, one would expect some differences due to the more specific focus of international development law, as well as some differences related to the history

${ }^{22}$ See generally Picker (International Law) (2008), supra note 3.

${ }^{23} I d$., p. 1102.

${ }^{24} I d .$, pp. $1103-1104$. 
of international development law. But where different from international law, the legal cultural analysis of international development law will be as provided in the next section.

Regardless of the precision of the analysis, and reflecting the methodology's value even in a very preliminary and generalized investigation, one is able to immediately identify initial questions, conclusions, and insights. For example, there is a question as to whether it is appropriate that the basic building blocks of international development law should come from the civil law and common law traditions. This question is especially pertinent given the presence of formal and informal non-western legal cultural elements in a vast number of developing countries. Another insight relates to the possibility that international development law, like international law and the Mixed Jurisdiction systems, will have to consider concerns related to language. ${ }^{25}$ For example, the possibility that the increasing use of English in the field might accentuate the role within international development law of the United States, Britain, and the other Englishspeaking countries. Relatedly, that the common law, through its strong connections to Anglophone states and English language legal materials, would also become increasingly influential in the field. Indeed, it might then be the case that those developing countries that include common law legal cultures or have significant facility in English would have a greater influence or be able to take advantage of international development law more than the other developing countries. All these possibilities are probably not in the best interests of the noncommon law and non-English language world - which are, in fact, the majority of the world. ${ }^{26}$

Other insights that can be derived from the comparative analysis of international law and applied to international development law include some technical legal cultural issues. Perhaps less obvious than linguistic imperialism is the issue of what law is imported into the system, the so called "path of reception". ${ }^{27}$ In other words, in the mixed jurisdiction analyses that were found to be applicable to international law, adoption of other legal devices, including legal cultural characteristics, often took place "when the civil law field is, relatively speaking, both general and vague." ${ }^{28}$ If applicable to international development

\footnotetext{
${ }^{25}$ See Mary Ann Glendon, Paolo G. Carozza, \& Colin B. Picker, Comparative Legal Traditions: Texts, Materials And Cases On Western Law (3rd ed., Thomson West Publishing, 2007), pp. $972-$ 82.

${ }^{26}$ There are 51 common law system states (which includes $35 \%$ of the population of the world), and there are 115 civil law system states (which includes $59 \%$ of the population of the world). See Wayne R. Barnes, Contemplating a Civil Law Paradigm for a Future International Commercial Code, 65 La. Law Review (2005), 677, 685.

${ }^{27}$ Picker (International Law) (2008), supra note 3, p. 1126.

${ }^{28}$ Ibid. (citing Vernon Valentine Palmer, "A Descriptive and Comparative Overview", in Vernon Valentine Palmer (eds.), Mixed Jurisdictions Worldwide: The Third Legal Family (Cambridge
} 
law, then it could be the case that there would be a similar trend of increasing or decreasing presence of western or Anglo-American or civil law concepts where international development law is not so well-defined or specific. Another way to think about it would be that where international development law is more amorphous, and hence not directly reflective of other legal cultures such as nonwestern ones, then Western legal culture will once again dominate-be it civil or common law in style. ${ }^{29}$

Furthermore, as international development law matures and becomes ever more "real", these issues will be even more apparent and the analysis ever more applicable. For example, when dispute resolution finally becomes a more common part of the international law of development, there will be a need to consider, as has been observed in the international law context, the character of the relevant litigation culture and whether it might conform to the trend in international law, like that in the mixed jurisdiction systems, where it tends to be common law-like. ${ }^{30}$ Also, the role of precedent will need to be more specifically considered in the context of the field. ${ }^{31}$

While necessarily brief, this analysis, predicated on a similarity between international law and international development law, can be powerful at fleshing out insights and questions. This is particularly helpful for the relatively less mature international development law as it may then be possible to predict and anticipate, and then to avoid, some of the issues that may arise as the field grows. Indeed, even if one were to argue that the field as a whole is not sufficiently comparable to international law, the above analysis and insights might be applicable to those parts of international development law that are similar to international law.

\section{B. Legal Cultural Analysis: International Development Sui Generis}

The question here is to identify the factors that would lead international development law to diverge from the general legal culture of international law, and then, if possible, to try to identify the character of those divergent legal cultural characteristics. This is no easy task, for while international law is a broad

University Press, 2001). ("Consequently, within mixed jurisdictions one finds greater common law intrusion in areas such as negligence. Another trend, at the opposite end of the spectrum, is that common law less commonly gains traction in those fields where the civil and common law concepts are diametrically opposed, such as in property law. Similarly, common law is not well received in areas of law with strong cultural aspects, such as family law." Id. (citations omitted)).

${ }^{29}$ The issues associated with the western versus non-western legal cultures will be discussed in greater detail below.

${ }^{30}$ Id., p. 1127.

${ }^{31}$ Id., p. 1125. 
field including within it radically different subfields (from the law of the sea to the law of war), international development law is also tremendously broad (covering everything from regulation of "infant industries" 32 to public health concerns). ${ }^{33}$ One should then expect that there may be large parts of international development law that are not sufficiently similar to international law, itself a broad field not easily amenable to legal cultural generalizations. Indeed, international development law in particular may be more likely than many other parts of international law to be different from the rest of international law, for there is much in it that is dissimilar to international law in substance, style, origins, and objectives.

As an initial matter, and outside the context of the civil and common law, it is likely that international development law will have a much greater presence of non-western legal culture as its objectives are most likely to be carried out in or concerning non-western countries than is the case for the rest of international law. This is further reinforced due to the consequently greater role of non-western origin scholars, jurists, and international law negotiators that will then work in the field. Indeed, the presence of non-western legal culture may be the single largest factor influencing the uniqueness of international development law. While those non-western countries will typically have significant western legal cultural components, ${ }^{34}$ there is no question that their legal systems will, in one way or another, include legal cultural issues that are not western and, as discussed below, they may consequently be different in ways that help or hinder development policy. Perhaps here is a good place to define western legal culture, hence to get a feel for what may be implied by a legal culture described as non-western. Western legal culture, existing not as a result of statute or case law, will have, among others, the following characteristics:

(1) [A] distinction between legal and other institutions, with law having an independent existence and identity from the other institutions;

(2) a theoretical separation of politics and morals from law;

(3) administration of the law by trained specialists--lawyers and judges;

(4) legitimate contributions of legal scholarship to the development of law;

(5) growth and change of law as part of a pattern of development;

(6) supremacy of law over political authorities;

(7) a view of the competing legal systems and jurisdictions as independently legitimate; and

\footnotetext{
${ }^{32}$ See GATT, art. XVIII.

${ }^{33}$ See World Development Indicators, World Banks reports, available at: $<$ http://data.worldbank.org/indicator $>$.

${ }^{34}$ See Barnes (2005), supra note 26.
} 
(8) endurance of the legal tradition even when legal systems are overthrown." 35

It should be noted that many legal cultural characteristics of the western legal tradition can also be found in non-western systems, but it is the full package together which defines the western legal tradition. International law does, at least as a formal matter, satisfy all these criteria and is hence solidly within the western legal tradition. ${ }^{36}$ But, to the extent that international development law does not include any of the above significant western legal tradition criteria, then its legal culture will depart ever further from international law's legal culture. As a de jure matter, international development law will satisfy these characteristics. It is when one gets down to the more direct interaction with individuals and domestic systems that there will be the greatest influence of non-western legal culture, usually at the de facto level. Accordingly, when domestic implementation is discussed below, the impact of non-western legal cultures will be discussed in greater detail.

Another legal cultural factor that may distinguish international development law from international law is that international development law is designed, among other things, to regulate asymmetric relations-from developed to developing and vice versa. International law, in contrast, usually applies between equals or deemed equals. The legal cultural reflections of the concepts of state equality and sovereignty are thus likely to be different for international development law. Another distinction is that there may be a normative content to international development law, not as typically recognized or accepted for other parts of international law. International law is, after all, a strongly positivistic legal system focused on states, while international development law is at times quite focused on the human condition. While international law will include nonpositivistic concepts, they are rare and confined to jus cogens and perhaps the fields of human rights and humanitarian law-fields that also typically focus on the human condition. It may be that the legal culture in those areas is also different from general international law.

These few examples show that at a generalized level there is a strong basis to believe that the legal culture of international development law is different in many respects to that of general international law. Nonetheless, in order to really identify the specific legal cultural characteristics that ensue from any similarity or difference to international law, it is necessary to delve into a more particularized examination, an atomistic examination. As is shown below, when that more detailed analysis is undertaken, using the examples of the interaction of

\footnotetext{
${ }^{35}$ Picker (International Law) (2008), supra note 3, pp. 1095-96, citing Harold J. Berman, Law and Revolution: The Formation of the Western Legal Tradition 7-10 (1983).

${ }^{36}$ Id., p. 1096.
} 
Picker: International Trade and Development Law: A Legal Cultural Critique

international development law and the WTO and domestic implementations, the legal cultural issues are more clearly laid bare, and one is then able to more effectively use those insights for the benefit of the field and as an example of the utility of the methodology.

\section{An Atomistic Legal Cultural Analyses of International DEVELOPMENT LAW}

The general insights derived from a brief holistic consideration of the legal culture of international development law must be reinforced by a more detailed atamostic consideration. An atomistic approach is typically more complicated and detailed than a holistic approach. However, it is also likely to be more accurate. A thorough atamostic analysis, however, would require significantly more coverage than can be provided here, which is not a problem given that the goal of this paper is merely to suggest a methodology rather than get hard results. In any event, such an atomistic analysis requires, as an initial matter, a review: (a) of the legal cultural issues of both the relevant international development law institutions and their substantive laws, and (b) of the many different legal cultural issues associated with domestic implementation of international development law in the hundreds of different legal cultures of the world.

\section{A. Legal Cultural Analysis of the WTO \& International Development Law}

A legal cultural analysis of an institution should consider which legal cultures predominate within that institution. ${ }^{37}$ In other words, is the institution dominated by western or non-western legal cultural characteristics, or by Anglo-American legal cultural characteristics versus those present in continental legal cultures. More specifically, it is also necessary to identify which aspects of the institution reflect which characteristics of the different legal cultures. Those aspects include the dispute resolution mechanisms, the participants' behaviors, the institution's secretariat, and so on. Similarly, substantive fields, when cohesive and well developed, can also be considered under a legal cultural analysis. The questions are then somewhat similar to those applied to international institutions: whether the field employs aspects from specific traditions and cultures, and whether the field is implemented in a way reminiscent of one of the traditions.

\footnotetext{
${ }^{37}$ See Colin B. Picker, "An Introduction to Comparative Analyses of International Organizations," Comparative Law and International Organizations: Cooperation, Competition and Connections, (Proceedings of the Swiss Institute of Comp. Law, forthcoming March 2011).
} 
Unfortunately, international development law has no one international institution or well defined substantive body of law in which it can be solely located. This is in contrast to other subfields of international law. For example, we can point to the WTO for trade; increasingly to the International Criminal Court for international criminal law; to the UN Convention on the Law of the Sea and its institutions for the oceans; and to the CISG/Unidroit for commercial law. While it might be argued that this "failing" of international development law is one of the strongest indicators for why there is really no such thing as "international development law", the lack of a central institution or body of law, while awkward, is not unusual in international law. Thus, even within the very sophisticated area of international investment law, we can see a similar situation, with a host of disparate institutions involved and with the law scattered throughout fora around the world. Indeed, the move to institutionalize and codify the fields comprising international law is of rather recent vintage. The role of the UN's International Law Commission over the last sixty years has been to identify, agree on, and then to codify parts of international law that exist in many different sources and about which there are often conflicting views. ${ }^{38}$

International development law does, however, exist as part of the work and objectives of numerous institutions and substantive fields. Those institutions include: international governmental organizations, non-governmental organizations, amorphous groupings of states and organizations, and a whole host of domestic participants, including the national and sub-federal governments as well as numerous domestic non-governmental organizations. Specifically, these bodies include: the WTO, the UN in general, more specific parts of the UN such as the UNCTAD, the International Chamber of Commerce (ICC), the OECD, the G7, the G8, the G20, the regional development banks, the EU, ASEAN, OAS, and many more international acronyms.

Substantively, it is the same story. International development law is not really a cohesive body of law so much as an unsystematic collection of hard and soft rules and regulations found across numerous systems. It exists within the law of other international fields and institutions, for the law of international development spans and penetrates many other discrete fields and systems. It also exists within States as a result of implementation of the various above international development laws, including through the Generalized System of Preferences (the "GSP") in developed countries, and numerous pro-development laws and institutions in developing countries themselves, such as efforts at development for indigenous groups or depressed areas. Not surprisingly, international development law does not apply monolithically. It impacts its different constituencies in different ways depending on who and what they are.

\footnotetext{
${ }^{38}$ See International Law Commission, available at: $<$ http://www.un.org/law/ilc/>.
} 
For example, states are impacted differently depending on their level of development and their economic model, such as whether they are market or nonmarket economies. International development law also impacts people differently, depending on ethnicity, race, tribe, religion, social class, geographic region, and so on.

Having described all that would go into an atomistical analysis, it is clear that a complete and atomistic legal cultural analysis of international development law would require legal cultural analyses across all international and other constituent parts. That is clearly too much for this present work. Accordingly, the only way then to conduct an atomistic legal cultural analysis of international development law is like all massive projects - with small steps, one step at a time. In this case, the steps are made up of those parts of international development law that are found in, implemented by, and under specific institutions, as assessed one institution at a time. In this paper, the institution chosen for the first step is the WTO. ${ }^{39}$

Like the analysis of international development law in international law above, the legal cultural analysis of the WTO's development law can be considered in one of two (binary) ways: (a) that it is like the rest of the WTO with respect to legal culture, or (b) that it is sui generis within the WTO with respect to legal culture. Of course, there will be parts of the WTO's development law that are unique and parts that are similar to the rest of the WTO. For those parts that are similar to the rest of the WTO, one can then apply the analysis conducted in part 1 below, and for those parts that are unique, we apply the analysis in part 2 below.

\section{WTO's development law is akin to the rest of the WTO}

If international development law within the WTO is akin to the rest of the WTO, then it should share legal cultural characteristics with the WTO. It has been argued that the WTO appears to be like a mixed system, with some characteristics closer to the common law and some closer to the civil law. ${ }^{40}$ While that research is still in process, some tentative conclusions have been drawn. In order to keep the length of this paper in check, only a few of those conclusions will be considered. They include, among other things, that:

\footnotetext{
${ }^{39}$ In any event, an atomistic examination of the WTO may end up constituting a significant part of any eventual definitive atomistic analysis, for the role of the WTO is quite significant for international development. Furthermore, its role in the growth of international development law will likely increase over the years, especially if the current "development" Round of the WTO is ever completed.

${ }^{40}$ See Picker (WTO) (2010), supra note 2.
} 
The WTO is more akin to the civil law in the large and significant role of scholars in guiding and creating the field.

The WTO is a bit of a "mixed bag" with respect to the civil law versus common law difference as to whether it exhibits greater evidence of doctrine (civil law) or pragmaticism (common law). The WTO contains some elements of system and theory, and some elements reflecting an ad hoc and pragmatic approach, with perhaps the latter increasingly tending to dominate.

The WTO employs strong de facto stare decisis, with the role of dispute settlement becoming ever more central to its law making!

The influence of Anglo-American law firms and legal education is significant.

The WTO Secretariat may be increasingly Anglo-American in character and style. $^{41}$

So, if the WTO's development policy largely falls in legal cultural line with the overall WTO, then we can say that, among other things:

The WTO's development law should reflect a mix of civil law and common law legal culture;

The role of scholars, largely from or trained in the western and developed world, may help determine the eventual legal culture of the field, and will correspondingly marginalize the contributions from the non-western developing world;

That its development policy may likely be subject to development through decisions of the WTO's Dispute Settlement Body (the "DSB") with all the legal cultural consequences that go with case driven legal development, or that little development law will take place due to the few development law cases handled by the law-creating DSB;

${ }^{41}$ Ibid. 
That it may likely develop as a result of pragmatic response to issues as opposed to development through doctrine and theory, though doctrine and principle may very well be present as an undercurrent; and

That we may see a disproportionate role for Anglo-American legal culture within the WTO, both at the DSB and within the Secretariat.

Using these initial inferences, one can then ask whether such legal cultural characteristics would prove to be beneficial or detrimental to the role of international development law within the WTO. The answer is likely to be that some of the characteristics might prove to be supportive while others might prove to be obstacles - indeed, some characteristics may be both supportive and be obstacles! For example, the likely growth of development law within the WTO through the DSB may be supportive, for the field is well served by the consistency of jurisprudence constante. Yet, the rationality of that consistency is not always assured, especially if only some cases make it to the dispute settlement system and not all cases proceed to the Appellate Body. Similarly, the field is also well served by the pragmatism that may be present in the WTO's development law, as opposed to holding up progress for the sake of ideal yet potentially unattainable goals. But, sacrificing principle for pragmatism may undermine the "correct" development of international development law. Finally, while the system seems to have permitted Anglo-American lawyers to assume a dominant position through their law firms gaining expertise in WTO litigation and through the AngloAmerican method within the Secretariat and global legal education, perhaps highly efficient developments, those influences clearly provide too much power to one legal culture and may come at the cost of capacity building and diversity of perspectives in the development of the field.

\section{WTO's Development Law is different from the rest of the WTO}

It is quite likely that the WTO's development law has many legal cultural characteristics different from the rest of the WTO. As an initial matter, most of those parts within the WTO dealing with development, certainly those parts that are not merely aspirational, take the form of exceptions to WTO obligations and liabilities as opposed to positive requirements. ${ }^{42}$ Another difference is that unlike much of the WTO, development is a central goal in its own right, ${ }^{43}$ not merely a device to achieve another goal. An example of the latter might be the Agreement

\footnotetext{
${ }^{42}$ See, for example, GATT, art. XVIII.

${ }^{43}$ See Marrakesh Agreement Establishing the WTO, preamble.
} 
on Article VI, whose goal is to minimize discriminatory treatment caused by WTO members manipulating anti-dumping and countervailing duty regulations.

Furthermore, perhaps more so than other parts of the WTO, there is a general division among the WTO members with respect to their positions on development policy that largely tracks the traditional power structure of the international legal order, and particularly of the international economic system. ${ }^{44}$ That divide is, of course, largely between those members that are developed versus those developing. In contrast, such divisions are not so applicable for the other parts of the WTO. For example, for the Agreement on Article VI, there will be a wide diversity among WTO members of responses and opinions, often changing over time depending on domestic politics.

Compounding the developed-developing member division within the WTO is the fact that most of the interested parties on the developing country side will have strong non-western legal tradition elements that may very well be reflected in their work on development within the WTO. Indeed, to the extent that the civilian/common law legal cultural characteristics are factors, as described earlier in the paper, there is even a developing country division there, for most of the "major" players from the developing world (e.g., Brazil and China) are not even part of the common law world. The one major exception is India, which has a codified common law and very strong non-western legal cultural components. ${ }^{45}$

Another issue that differentiates the development part of the WTO from the rest of the WTO is that non-economic factors may loom larger with respect to the goals of development policy than might be the case in the other policy areas of the WTO - regardless of application of the "traditional" or "modern" perspectives in international development law. For example, for trade remedies, MFN and national treatment, the measurement of success will be more closely tied to classical economic factors and indicators. In contrast, development, while for sure concerned with such economic indicators in its goals, must also be focused on a wide variety of other non-economic goals, such as those identified by the World Bank. ${ }^{46}$ Those goals include consideration of economic as well as non-economic criteria, such as reductions in infant mortality, access to potable water, and so on. ${ }^{47}$ Relatedly, one may see a higher level of normative considerations, even

\footnotetext{
${ }^{44}$ See An Chen, "A Reflection on the South-South Coalition in the Last Half-Century from the Perspective of International Economic Law-Making: From Bandung, Doha and Cancun to Hong Kong", in Yong-Shik Lee (eds.), Economic Development through World Trade: A Developing World Perspective (Kluwer Law International, 2008).

${ }^{45}$ See John Armour and Priya Lele, Law, Finance and Politics: the Case of India, 43 Law \& Society Review (2009), 491, 499.

${ }^{46}$ See World Bank, supra note 33.

${ }^{47}$ Id. See also Colin B. Picker (Picker (Developing)), Neither Here Nor There-Countries that Fall Between the Developed and the Developing World in the WTO, 36 George Washington International Law Review (2004), 147, 150.
} 
Picker: International Trade and Development Law: A Legal Cultural Critique

morality, in the development law debate within the WTO. While there is disagreement over trade remedies and regional trade agreements, the discussion rarely leads to discussions of what is the "moral thing to do" as may be the case when infant mortality is at stake! Accordingly, the legal cultural consequence may be a relatively smaller role for economics and a greater role for morality in the legal culture of that part of the WTO dealing with development. This may perhaps further isolate development policy from the normatively neutral and economically focused legal culture of the WTO.

Ironically, even as development law's goals look beyond trade and economics, another difference between the development part of the WTO and the rest of the WTO is that it is an area, more than others, held hostage to non-trade and often non-economic goals, albeit different ones than discussed above! This issue is most clearly seen in the context of GSP conditionality, where that preferential access is very often conditioned upon the developing country satisfying western and developed world conditions, such as the condition of not being designated a "supporter of terrorism". 48 Sometimes that conditionality does have a tenuous relationship to international economic matters, albeit those matters of particular high priority to developed and western states. In those cases the conditionality is based upon the developing country being considered, among other things, an enforcer of international arbitral awards, intellectual property rights, and labor rights. ${ }^{49}$ Very often those issues are simply inapplicable in the developing country or of relatively low priority given the conditions within that country. ${ }^{50}$ Yet, most other areas of the WTO, for GSP exists as an authorized exemption to $\mathrm{MFN},{ }^{51}$ are not similarly conditioned. While it is unclear exactly what might be the legal cultural consequences of this issue, it is clear that there will be some. Perhaps the legal cultural consequence may be, among other issues, the creation of a siege mentality, in which even useful foreign legal cultural issues, such as enforcement of arbitral awards, may be rejected or resented.

\footnotetext{
${ }^{48}$ See, for example, U.S. Generalized System of Preferences Guidebook, at 20, available at: $<$ http://www.ustr.gov/webfm_send/1597>.

${ }^{49}$ Id., pp. 20-21.

${ }^{50}$ See Picker (Developing) (2004), supra note 47, pp. 157-158.

51 " $(\mathrm{T})$ he provisions of Article I shall be waived for a period of ten years to the extent necessary to permit developed contracting parties .. . to accord preferential tariff treatment to products originating in (DCs) . . . without according such treatment to like products of other contracting parties." Generalized System of Preferences, GATT Doc. L/3545 (25 June 1971). These preferences were made permanent in 1979 through the "enabling clause" of the Tokyo Round's Texts Concerning a Framework for the Conduct of World Trade. This GATT act was later affirmed by the WTO, see General Agreement On Tariffs And Trade - Multilateral Trade Negotiations (The Uruguay Round): Ministerial Decisions And Declarations 33 I.L.M. (1994), 136.
} 
History also differentiates the WTO's development policy from the rest of the WTO, with concomitant legal cultural consequences. While all of the WTO is closely associated with the historical developments of the last one hundred years, and in particular that of the interwar period, it may be the case that the development part of the WTO is more closely tied to recent or different histories. Clearly, the history and legacy of colonialism (neo and otherwise) and decolonization is more relevant to the GATT's and then the WTO's development provisions than to other parts of the WTO. ${ }^{52}$ Indeed, history may be more relevant to development than is the case for trade law in general. Thus, the legacy of colonization continues to reverberate through the present development trade policy in a more significant manner than is the case of such historically significant events for the WTO as the Smoot Hawley Tariff Act of 1930. True, that Act and other economic historic events of the 1930s were talked about during the recent recession, but the trade system has already addressed the problems that led to those historic events in Article II's tariff bindings and in other parts of the GATT/WTO. ${ }^{53}$ In contrast, the continuing impact of neo-colonialism and the post colonial legacy continue to haunt development policy within the WTO. Perhaps the legal cultural consequence for development law in the WTO is to cast a backward looking sheen onto the legal culture, thereby undermining any forward thinking or growth in the legal culture and field.

The legal culture of development law within the WTO is bound to be impacted by the fact that development law within the WTO is now part of a major realignment and power shift within the WTO. The previous dominant members, developed and western members, are now finding their power challenged by a developing country bloc within the WTO. ${ }^{54}$ That bloc is now demanding that the WTO resolve developing country needs before it agrees to any changes to the WTO. The Doha Round, otherwise named the "Development Round" was launched with that very goal, and its failure to meet those demands is one of the major obstacles to completion of the Round. After all, given the consensus method for approving change in the WTO, the developing countries essentially have a veto over any future changes within the WTO. Thus, development law in the WTO has now assumed a very high level of significance and priority, and until it is resolved to the satisfaction of the developing countries, progress of all

\footnotetext{
${ }^{52}$ See, for example, Ruth Gordon, Sub-Saharan Africa and the Brave New World of the WTO Multilateral Trade Regime, 8 Berkeley Journal of African-American Policy Review (2006), 79, 86. ${ }^{53}$ Additionally, within the United States, the Congress realized that it should not be involved when it came to setting line item tariffs, and has ever since delegated that authority to executives who are more immune to the pressures that led to the Congressional "pork barrel" and "log rolling" that created that infamous tariff act. See Sungjoon Cho, Toward a New Economic Constitution: Judicial Disciplines on Trade Politics, 42 Wake Forest Law Review (2007), 167, 174.

${ }^{54}$ See Lee (2008), supra note 17, pp. 5-6.
} 
other areas of trade negotiation may be held hostage. ${ }^{55}$ It is hard to predict what impact this elevation of WTO development law and developing countries will have on the legal culture. Perhaps it will give strength to that part of the legal culture experiencing pressure from the developed and western world. Perhaps it will lead to greater isolation as attitudes harden and positions form at opposite ends of the arguments. It is too early to really discern the impact, but it is hard to believe it will not impact the legal culture of international development law.

Finally, a major area in which the legal culture of the WTO's development law will be different is in the fact that there is a relatively diminished role for the dispute settlement system both in creating development law within the WTO and in handling the WTO issues of developing countries. ${ }^{56}$ There are many reasons to explain this deficit, including that there have been relatively few disputes directly related to the specific substantive law of development within the WTO. In part that is because much of the law of development within the WTO is aspirational or discretionary and there then is less opportunity for those disputes to rise to an actionable level. Additionally, leaving the large countries of Brazil, China, and India aside, the asymmetric relationships between developed and developing countries, between whom the development law disputes would take place, militates against disputes being brought to the dispute settlement body, and hence the opportunity for development law to be heard at the DSB. Developed countries have little to gain (economically) and much to lose (politically) by bringing cases against developing countries in most cases. Developing countries, on the other hand, have few resources in which to bring disputes against often vastly better resourced developed countries. ${ }^{57}$ Additionally, even if they prevail, there may be political, and hence economic, costs. Finally, their ability to use authorized retaliation against developed countries would appear to be very limited, though this may be changing. ${ }^{58}$ The consequences of this situation will be visible in WTO development law legal culture in many ways - from less litigiousness to a diminished role for common law and western legal culture in development law in the WTO. The latter is a consequence of less employment of Anglo-American law firms. Similarly, due to less disputes on development law, there will consequently be less involvement of the developed countries, with a correspondingly smaller impact of those countries on the development of the law through the DSB. The

\footnotetext{
${ }^{55} \mathrm{Id}$.

${ }^{56}$ See Kara Leitner \& Simon Lester, WTO Dispute Settlement 1995-2009--A Statistical Analysis, 13 Journal of International Economic Law Review (2010), 205, 207-10; see also Chad P. Bown, Self Enforcing Trade: Developing Countries and WTO Dispute Settlement (Brookings, 2009) at Chapter 4.

${ }^{57}$ Id., pp. 93-97.

${ }^{58}$ Id., pp. 134-35.
} 
law may therefore remain closer to the treaties and principles. In that way, it may be more civilian in content.

These few insights, from both the analysis of the WTO's development law as similar to and as different from the WTO, suggest that the legal cultural characteristics of the WTO and its development law will clearly have an impact on development policy within the WTO. In order to understand the full impact, however, it is necessary to wait for the completion of the legal cultural analysis of the WTO that is in process, and of which this paper is but one small part. Furthermore, without consideration of the domestic implementation of WTO development law, discussed below, the story is necessarily incomplete. Much of the WTO policy, development or otherwise, takes place within the member states, through domestic implementation of WTO rights and obligations. Hence the atomistic analysis, and the presentation of the methodology, next requires a legal cultural analysis of the domestic implementation of international development law.

\section{B. Domestic Implementation of International Development Law}

An atamostic legal cultural analysis of international development law requires a consideration of how it is applied by and within states. This is necessary because international legal fields, such as international development law, must often work within domestic legal systems, and as such they will directly interact with those domestic legal traditions. Even leaving aside the issue of legal culture, domestic implementation is highly problematic, with issues ranging from partial implementation to inconsistent and often opposite interpretations of the international obligations by national courts. ${ }^{59}$

Many of the problems with implementation may, however, be caused by legal cultural disconnects. Needless to say, there are numerous domestic legal cultural issues that will present positive or negative issues for implementation of international development law. Indeed, within every state's legal system, regardless of the level of development or legal tradition background, there will be legal cultural characteristics with an impact on the implementation of international development law. Furthermore, because the legal culture is different in all states, sometimes radically different, consideration of all the legal cultures is

\footnotetext{
${ }^{59}$ See Kai Schadbach, The Benefits of Comparative Law: A Continental European View, 16 Boston University International Law Journal (1998), 331, 385-86. Compare E. Airlines, Inc. v. Floyd, 499 U.S. 530, 552 (1991), holding that the Warsaw Convention does not cover damages for emotional distress; $i d$. ., p. 551, noting the sole decision from a sister signatory court concerning recovery for mental damages found that Article 17 should be read expansively to include damages for psychic injuries (citing Air France v. Teichner, 38 (III) P.D. 785, 788 (1984) (Isr.)).
} 
simply not possible here. Accordingly, this paper will only discuss some of the common issues that apply in many of the developing countries. Clearly, however, an aggregation of country specific studies and surveys is the best method for seeing the complete picture. ${ }^{60}$

As an initial matter, the discussion earlier in the paper concerning the civilian and common law characteristics of international development law may prove to be a source of legal cultural disconnect or concordance for domestic implementation, depending on whether the domestic system employs a similar characteristic. Thus, if international development law develops pragmatically, then there would likely be problems for those domestic legal cultures that exist within a logical, principled and scientific legal system. Similarly, there will be a legal cultural disconnect between domestic legal cultures that exist within a common law system and those parts of international development law that are civilian-like.

Regardless of its civil or common law components, international development law is for the most part western. This is necessarily so, as it is a part of international law operating within international institutions and usually created on the developed western world's terms. As such, there are few formal parts of international development law that will not be western, despite a clear need to take non-western legal culture into account. Therefore, the single largest disconnect at the domestic state level, outside the civil/common law issues described above, will be the result of western international development law attempting to fit with or being implemented within non-western systems or those parts of domestic law which reflect non-western legal cultural characteristics. Given that a great majority of the developing world will reflect non-western legal cultural issues in their legal culture, this source for cultural disconnects may be rather significant. This is not to suggest that in developing countries the western legal culture is absent, so much as to say it may be significantly less present than in the developed countries. Though even in western systems, sometimes nonwestern legal cultural issues will be present. For example, religious legal traditions and cultures may be present in western systems, very often in the areas of family law and inheritance. ${ }^{61}$

Part of the explanation for the presence of the non-western legal cultural characteristics is that while most developed states have either adopted the common law or civil law traditions (via direct or legal colonialism/imperialism), ${ }^{62}$

\footnotetext{
${ }^{60}$ See, for example, Picker (China) (2011), supra note 2. The author is also presently working on one focused study of the United States legal culture and its interaction/implementation with the WTO, but an initial idea of some of the ideas may be found at Picker (Methodology) (2011), supra note 2 .

${ }^{61}$ See Glendon (2007), supra note 25, pp. 968-70.

${ }^{62}$ See Barnes (2005), note 26. See also Glendon (2007), supra note 25, pp. 68 and 320.
} 
they still retained vestiges of their own pre-western systems-either as explicit legal characteristics that survived as unwritten law or exist through the western legal cultural characteristic being filtered through non-western filters. As a result, many of the western legal cultural criteria (see above) are absent in the legal culture of developing countries, either as a formal or informal matter. This issue is easily demonstrated by consideration of a few examples from African legal culture, where in many cases these criteria are absent or severely weakened. Of course, any employment of the generalization of Africa as one unit, whether of legal culture or otherwise, is clearly problematic, for there are numerous legal cultures within that continent. ${ }^{63}$ But that generalization is one that has been used by others in the past, including experts on African cultures and on whose work I now rely. ${ }^{64}$ Also, rather than it being a generalization, the examples here are merely ones that are not uncommon throughout much of African legal culture and are ones selected precisely because they are relevant to the paper. For example, the Western legal cultural characteristic of change and dynamism within the law may be culturally less present in Africa, in which the past may figure larger in minds. ${ }^{65}$ Given the dynamic nature of international development law, this may present a significant legal cultural obstacle to its implementation. Similarly, the role of religion is a significant force throughout Africa, even going so far as to imbue secular law with "religious or transcendent" significance. ${ }^{66}$ That role of religion may likely impact the place of positivism within the legal culture. ${ }^{67}$ International development law, despite its heavy normative basis, must still rely on positive law to achieve its goals. Anything which undermines the role of positive law may necessarily undermine the implementation of international development law. Thus, these few examples from African legal culture clearly show the clash with international development law that may arise as a result of some of the non-western characteristics within legal cultures in the developing world.

\footnotetext{
${ }^{63}$ The diversity within Africa is immense, with classifications including: Black Africa, White Africa, Saharan Africa, sub-Saharan Africa, Nile Delta Africa, Western Africa, Southern Africa, Francophone Africa, Anglophone Africa, Arabophone Africa, Lusophone Africa, tribal Africa, and so on. The list is endless. See Daniel Etounga-Manguelle, "Does Africa Need a Cultural Adjustment Program", in Lawrence E. Harrison \& Samuel P. Huntington, (eds.), Culture Matters How Values Shape Human Progress (Basic Books, 2000), p. 67.

${ }^{64}$ Id. See John Henry Merryman, David S. Clark, and John Owen Haley, Comparative Law: Historical Development of the Civil Law Tradition in Europe, Latin America, and East Asia (LexisNexis, 2010), p. 16.

${ }^{65}$ Etounga-Manguelle (2000), supra note 63, p. 69.

${ }^{66}$ Merryman (2010), supra note 64, p. 19.

${ }^{67}$ Etounga-Manguelle (2000), supra note 63, p. 70.
} 
Picker: International Trade and Development Law: A Legal Cultural Critique

A specific, but large, subset of non-western legal culture is that of indigenous peoples. ${ }^{68}$ Indigenous peoples' legal heritage has been described as chthonic, keeping with the earth and its rhythms. ${ }^{69}$ As such, there is a possibility that states where chthonic legal culture remains may be more open to the "modern" or NIEO form of international development law, with its holistic approach. To the extent that international development law focuses solely on individual projects from an economic perspective alone, leaving states to handle separately the environmental and social policies otherwise involved, there may be a disconnect between a legal culture that views all these things as related and not divisible. ${ }^{70}$ In addition, chthonic legal culture in some cases has also been opposed to the writing down of laws, as it is believed that oral transmission is superior and appropriate. ${ }^{71}$ To the extent transparency is a part of international development law, this may present some implementation issues. Similarly, in chthonic legal cultures, as in communal legal cultures, the adjudication and law are accessible to all, with no barriers. ${ }^{72}$ That open access characteristic may clash with those parts of international development law that are less open. Indeed, international development law may exist and be developed within the relatively closed WTO, closed in adjudication and closed in access to sources, both confidential sources and ones so complex as to essentially not be available. Similarly, some chthonic legal cultures, while open to trade, have some highly restrictive characteristics with respect to commercial activities, including some that might be thought to stand in the way of development, though it is more likely that they simply need to be managed differently. ${ }^{73}$ Finally, and perhaps quite crucially, the role of the state does not fit well with chthonic tradition. ${ }^{74}$ This is evident in the revival in Africa and central Asia of "community-clan institutions". ${ }^{75}$ Relatedly, there may be a cultural disconnect as a result of the topdown decision making in domestic law, which inevitably arises as a result of the fact that international law implementation is typically handled by national governments, and not sub-federal entities, regions, or even peoples. ${ }^{76}$ Finally,

68 "There are over 370 million indigenous people in some 90 countries, living in all regions of the world." UN Permanent Forum of Indigenous Peoples, State of the World's Indigenous Peoples, available at: <http://www.un.org/esa/socdev/unpfii/en/sowip.html>.

${ }^{69}$ See H. Patrick Glenn, Legal Traditions of the World (4th ed., Oxford, 2010), p. 63.

${ }^{70}$ Bradlow (2004), supra note 1, pp. 200-201.

${ }^{71}$ Glen (2010), supra note 69, p. 64.

${ }^{72} I d$., pp. 67-68.

${ }^{73}$ See Glen (2010), supra note 69, pp. 68-69 \& n. 29.

${ }^{74} I d$., p. 86.

${ }^{75} \mathrm{Id}$.

${ }^{76}$ See Colin B. Picker, "Islands of Prosperity and Poverty: A Rational Trade Development Policy for Economically Heterogeneous States", in Yong-Shik Lee, Won-Mog Choi, Tomer Broude, \& Gary Horlick (eds.), Law and Development Perspective on International Trade Law, (Cambridge University Press, forthcoming 2011). 
there may be conflicts with respect to individual property rights obligations and community or tribal notions of collective property within international development law implementation, specifically in the intellectual property and investment contexts. $^{77}$

Of course, in part because international development law already includes or should include more non-western legal cultural characteristics, there will also be non-western legal cultural characteristics that might support the implementation of international development law within developing countries. For example, and continuing with African examples, there are greater communal and tribal law legal cultural characteristics in Africa. ${ }^{78}$ This may support development law which often requires community involvement, although this communal legal cultural characteristic must be balanced against the corresponding diminishment of individualism that may exist within African legal culture. ${ }^{79}$ This then presents a legal cultural disconnect with international development law to the extent that individualism, via western legal culture, is a part of international development law. ${ }^{80}$ Thus, it really then depends on the specific part of international development law at issue as to whether greater communal legal cultural characteristics will help or hinder international development law. Indeed, because the present international development law is so very western in character, one may wonder whether it will be possible to find an unambiguous case of a nonwestern legal cultural characteristic that clearly supports international development law.

Further complicating the issue, there may also be aspects of Western law that inhibit the implementation of international development law! This may be especially so for implementation in western states, when or if they ever are forced to deal with aspects of international development law which are non-western, such as support for community property rights. Also, there may be a legal cultural clash with western legal cultures that may result from attempted application of the "modern view" of international development law-which may help to explain the hostility of the developed and western world to the "modern" perspective on international development law. After all, application of that view may require a consideration of non-economic matters associated with environmental, social, historical, and other non-law considerations. Furthermore, any effort to bring consideration of matters of justice into international development law

\footnotetext{
${ }^{77}$ See, for example, Lorie Graham \& Stephen McJohn, Indigenous Peoples and Intellectual Property, 19 Washington University Journal of Law and Policy (2005), 313.

${ }^{78}$ Etounga-Manguelle (2000), supra note 63, p. 71.

${ }^{79} I d$., p. 71.

${ }^{80}$ See Mark Van Hoecke \& Mark Warrington, Legal Cultures, Legal Paradigms and Legal Doctrine: Towards a New Model for Comparative Law, 47 International Comparative Law Quarterly (1998), 495, 503.
} 
Picker: International Trade and Development Law: A Legal Cultural Critique

implemented in western states may prove equally unpalatable. Western legal culture more easily accepts the notion of "justice under law" as opposed to other notions of justice that are thought to be outside the context of law. All of these issues could easily lead to legal cultural disconnects for western legal culturewhere law is, as a theoretical matter, separate from politics and morality.

\section{CONCLUSION}

While this paper is mainly concerned with presenting an example of a methodology in action, it also identifies some issues and insights about international development law. Perhaps the single largest conclusion is the critical interaction of non-western legal cultures with international development law. Additionally, it appears that regardless of which analysis of international development law within international law or within the WTO was applied (whether akin to international law/WTO or sui generis), the results were surprisingly similar-suggesting that the legal cultural issues may be widespread and deeply imbedded.

Even the preliminary analysis provided in this paper helps to explain the relative lack of success and ineffective application of international development law within international law, within the WTO, and within domestic systems. That analysis clearly identifies many examples where the legal culture of international development law simply does not fit with international law or the WTO and has difficulties being implemented within domestic systems. But, as serious as some of these legal cultural disconnects appear, the fact is that while "sticky", many of them can be managed if identified and confronted. Indeed, one of the central goals of the proposed methodology is to assist in such identifications and suggest ways of how those legal cultural obstacles can be managed. Typically, the solution will be based on the legal cultural characteristic itself or will be molded to deal with the foreign legal cultural characteristics with which it clashes. Furthermore, as international development law grows, in order to proactively deal with potential legal cultural clashes, the specific areas of growth should be considered under a legal cultural analyses. They should then be examined against comparable legal cultural issues within general international law and within the WTO, and any lessons derived from those comparative examinations should be applied early in the formation of the new development policies.

Finally, because this paper is part of a larger project that is presently in process, it should, when that work is completed, be read in conjunction with those other papers. Doing so will provide a more detailed and broader picture of the issues involved, thus providing a better picture of the operation and effectiveness of the proposed legal cultural methodology - a methodology that can be applied 
beyond international development law into international law and its many subfields.

\section{REFERENCES}

American Law Institute, Restatement (Third) Foreign Relations §101 (1986).

Armour, John and Priya Lele, Law, Finance and Politics: the Case of India, 43 Law \& Society Review (2009).

Barnes, Wayne R., Contemplating a Civil Law Paradigm for a Future International Commercial Code, 65 LA Law Review (2005).

Bown, Chad P., Self Enforcing Trade: Developing Countries and WTO Dispute Settlement (Brookings, 2009).

Bradlow, Daniel D., Development Decision Making and the Content of International Development Law, 27 Boston College International and Comparative Law Review (2004).

Chen, An, "A Reflection on the South-South Coalition in the Last Half-Century from the Perspective of International Economic Law-Making: From Bandung, Doha and Cancun to Hong Kong”, in Yong-Shik Lee (eds.), Economic Development through World Trade: A Developing World Perspective (Kluwer Law International, 2008).

Cho, Sungjoon, Toward a New Economic Constitution: Judicial Disciplines on Trade Politics, 42 Wake Forest Law Review (2007).

Etounga-Manguelle, Daniel, "Does Africa Need a Cultural Adjustment Program", in Lawrence E. Harrison \& Samuel P. Huntington (eds.), Culture Matters How Values Shape Human Progress (Basic Books, 2000).

Glendon, Mary Ann, Paolo G. Carozza, \& Colin B. Picker, Comparative Legal Traditions: Texts, Materials And Cases On Western Law (3rd ed., Thomson West Publishing, 2007).

Glenn, Patrick and H. Patrick, Legal Traditions of the World (4th ed., Oxford University Press, 2010).

Glennon, Michael J., The Blank-Prose Crime of Aggression, 35 Yale Journal of International Law (2010).

Gordon, Ruth, Sub-Saharan Africa and the Brave New World of the WTO Multilateral Trade Regime, 8 Berkeley Journal of African-American Policy Review (2006).

Graham, Lorie and Stephen McJohn, Indigenous Peoples and Intellectual Property, 19 Washington University Journal of Law and Policy (2005).

Hoecke, Mark Van and Mark Warrington, Legal Cultures, Legal Paradigms and Legal Doctrine: Towards a New Model for Comparative Law, 47 International Comparative Law Quarterly (1998). 
Picker: International Trade and Development Law: A Legal Cultural Critique

Lee, Yong-Shik, "Development and the World Trade Organization: Proposal for the Agreement on Development Facilitation and the Council for Trade and Development in the WTO", in Yong-Shik Lee (eds.), Economic Development through World Trade: A Developing World Perspective (The Hague: Klumer Law International, 2008).

Leitner, Kara and Simon Lester, WTO Dispute Settlement 1995-2009--A Statistical Analysis, 13 Journal of International Economic Law Review (2010).

Merryman, John Henry, David S. Clark, and John Owen Haley, Comparative Law: Historical Development of the Civil Law Tradition in Europe, Latin America, and East Asia (LexisNexis, 2010).

Paul, J. R., Cultural Resistance to Global Governance, 22 Michigan Journal of International Law (2000).

Picker, Colin B., "A Framework for Comparative Analyses of International Law and its Institutions: Using the Example of the World Trade Organization", in E.C. Ritaine, S.P. Donlan, and M. Sychold (eds.), Comparative Law and Hybrid Legal systems (Swiss Institute of Comp. Law, 2010).

China, Global Governance \& Legal Culture: The Example of China \& the WTO, Parts 1 of 4, Proceedings of the University of Tokyo Institute of Social Science (forthcoming January 2011).

"Islands of Prosperity and Poverty: A Rational Trade Development Policy for Economically Heterogeneous States", in Yong-Shik Lee, Won-Mog Choi, Tomer Broude, \& Gary Horlick (eds.), Law and Development Perspective on International Trade Law, (Cambridge University Press, forthcoming 2011).

Comparative Law Methodology \& American Legal Culture: Obstacles and Opportunities, Roger Williams University of Law Review (forthcoming January 2011).

International Law's Mixed Heritage: A Common/Civil Law Jurisdiction, 41 Vanderbilt Journal of Transnational Law (2008).

Colin B. Picker, Beyond the Usual Suspects: Application of the Mixed Jurisdiction Jurisprudence to International Law and Beyond, 3 Journal of Comparative Law (2008).

Neither Here Nor There-Countries that Fall Between the Developed and the Developing World in the WTO, 36 George Washington International Law Review (2004).

Schadbach, Kai, The Benefits of Comparative Law: A Continental European View, 16 Boston University International Law Journal (1998).

World Trade Organization, European Communities - Measures Affecting Meat Products (Hormones), WT/DS26/AB/R (16 January 1998). 